\title{
DNA Raw Data Analysis for Better Health Outcomes
}

\section{Mohammed $\mathbf{S}^{1,2 *}$ and Rub $\mathrm{A}^{1}$}

${ }^{1}$ Department of Bioinformatics, University of Nebraska-Lincoln, USA

${ }^{2}$ Xcode Life Sciences Private Limited, Chennai, Tamil Nadu, India

\begin{abstract}
The advent of low-cost sequencing and genotyping technologies has made DNA data widely accessible to individuals. Ancestry DNA tests (from companies like 23andMe, Ancestry DNA, Family Tree DNA etc.) continue to be one of the most popular genetic tests in this space. Over 15 million genetic tests have been sold so far by ancestry genetic testing companies. These companies also empower the end consumer by sharing their raw DNA data with them. While predicting ancestry and haplogroups (Mt and $\mathrm{Y}$ ) is just one component of doing the test, the more actionable applications of having raw DNA data lie in the area of health, wellness, nutrition, fitness, precision medicine and more.
\end{abstract}

Keywords: DNA raw data; Nutrigenetics; Precision medicine; Ancestry; Fitness genetics; DTC companies

\section{Introduction}

\section{Application of DNA test results in diet and nutrition}

Nestle recently launched their "Nestle Wellness Ambassador" program in Japan. The Nestle Wellness Ambassador program utilizes DNA raw data as well as biochemical parameters to carve out a personalized nutrition plan for individuals participating in this program. Another US based company called Habit, delivers food based on a DNA/genetic test. There have been several studies demonstrating the impact of DNA polymorphisms on our food intake and preferences. Hyper-personalized diets based on a genetic test are catching up. Early movers like Nestle, Habit and others believe that by combining nutrigenetics and microbiome testing, food can have a major impact in increasing longevity and improving the quality of living.

\section{Use of genetic testing in sports and fitness}

According to the US National Library of Medicine and other studies on twins, genetic factors contribute to $30-80 \%$ of the differences among individuals in traits related to athletic performance [1,2]. In Aug 2018, China announced that gene marker status will be an important attribute in the selection procedure for the 2022 Winter Olympics. The DNA of prospective participants will be subjected to Whole Genome Sequencing (WGS) to test for the presence of specific genetic markers. Some well-studied genetic markers associated with athletic performance include ACE, ACTN3, and PPARG. For example, Single Nucleotide Polymorphisms (SNPs) in the ACTN3 gene have been linked to the muscle fibre type (fast twitch/slow twitch). Similarly, ACE polymorphisms have been linked to strength and endurance. China is not the only country with this initiative. While not mainstream, several studies have been conducted on athletes from Russia, Australia, South Africa and United States. The next generation of sports athletes will most likely combine genetic information on top of the rigorous training, to up their game.

\section{Impact of DNA analysis on health}

In March 2018, the US Food and Drug Administration (FDA) authorized 23andMe to report on BRCA1- and BRCA2-related genetic risk for breast, ovarian, and prostate cancer. This is the first time a Direct-To-Consumer (DTC) company has been allowed to report cancer variants directly to their customers. The applications of this major milestone might be narrow as it focuses specifically on the Ashkenazi Jewish population. Yet, what needs to be appreciated is the direction in which the genetic testing field is moving. Similarly, the APOE gene variants (E4) that influence the risk for Alzheimer's disease, can be determined by simple genetic tests which cost under $\$ 99$. Such tools and tests barely existed 15 years back and even if they did, were prohibitively expensive. Khera et al. recently demonstrated that a polygenic risk score derived from a large number of markers on a genotyping chip can be a useful tool for risk stratification for common diseases [3]. For individuals who believe that knowledge is empowering, knowing risk variants and compounding them with other biomedical parameters, family history and clinical risk factors can add immense value in disease diagnosis and prevention.

\section{DNA and precision medicine}

It is common knowledge that standard doses of medicines work

\begin{tabular}{|c|c|c|}
\hline $\begin{array}{c}\text { CYP2D6 Metabolizer } \\
\text { Status }\end{array}$ & Alleles & Geographical Distribution \\
\hline $\begin{array}{c}\text { Ultrarapid Metabolizers } \\
\text { (UMs)-Increased } \\
\text { activity of the enzyme. } \\
\text { Higher risk of toxicity }\end{array}$ & 2 fully functional alleles & $\begin{array}{c}16 \% \text { of Ethiopians, 3-5\% of } \\
\text { Caucasians, 2\% of Swedish } \\
\text { Caucasians. UMs are present } \\
\text { in Oceania and North Africa. }\end{array}$ \\
\hline $\begin{array}{c}\text { Extensive Metabolizers } \\
\text { (EM)-Normal to } \\
\text { increased activity of the } \\
\text { enzyme }\end{array}$ & $\begin{array}{c}\text { One fully functional and } \\
\text { one allele with reduced } \\
\text { function }\end{array}$ & $70-80 \%$ of Caucasians \\
\hline $\begin{array}{c}\text { Intermediate } \\
\text { Metabolizers (IM)- } \\
\text { Reduced activity of the } \\
\text { enzyme }\end{array}$ & $\begin{array}{c}2 \text { alleles with reduced } \\
\text { function or 1 allele with } \\
\text { reduced function and } \\
\text { one non-functional allele }\end{array}$ & $\begin{array}{c}10-17 \% \text { of Caucasians. IMs } \\
\text { are found mainly in Asia. }\end{array}$ \\
\hline $\begin{array}{c}\text { Poor Metabolizers } \\
\text { (PM)-Greatly reduced } \\
\text { or no activity of the } \\
\text { enzyme }\end{array}$ & 2 non-functional alleles & $\begin{array}{c}19 \% \text { of African Americans, } \\
5-10 \% \text { of Caucasians, 1\% } \\
\text { Chinese population and 0.6\% } \\
\text { of South Indian population. } \\
\text { PMs are found mainly in } \\
\text { Europe. }\end{array}$ \\
\hline
\end{tabular}

Table 1: Metabolizer status of CYP2D6 and corresponding allelic frequencies in various populations.

*Corresponding author: Dr. Saleem Mohammed, Department of Bioinformatics, University of Nebraska-Lincoln, USA, Tel: 095432 89999; E-mail: info@xcode.in

Received October 23, 2018; Accepted November 10, 2018; Published November 14, 2018

Citation: Mohammed S, Rub A (2018) DNA Raw Data Analysis for Better Health Outcomes. J Mol Genet Med 12: 378 doi:10.4172/1747-0862.1000378

Copyright: (C2018 Mohammed S, et al. This is an open-access article distributed under the terms of the Creative Commons Attribution License, which permits unrestricted use, distribution, and reproduction in any medium, provided the original author and source are credited 
well for most individuals. However, a better understanding of the genetic basis of drug response, will empower doctors to prescribe drugs in their right or optimal doses that are best suited for each individual. This serves to enhance the safety and efficacy of the treatment. For example, CYP2D6 is one of the most important enzymes associated with detoxification. Around $25 \%$ of the clinical drug clearance is carried out by this enzyme, which includes anti tumor drugs and antipsychotic drugs. This enzyme constitutes $40 \%$ of the human hepatic phase I metabolism. The Clinical Pharmacogenetics Implementation Consortium (CPIC) has categorized various drug metabolizing enzymes along with their implications. Table 1 outlines one such piece of information for the CYP2D6 enzyme. The right medication along with the right dose can be determined using DNA data to reduce burden of costs and prevent side effects.

\section{Discussion and Conclusion}

\section{Using genetic genealogy in research studies}

A large amount of DTC genetic tests was made famous primarily by genealogists and ancestry enthusiasts. Having precise ancestry information can be immensely helpful in order to determine disease risks as well as to identify novel mutations occurring in specific populations. Saleheen et al. showed that in a specific consanguineous community in Pakistan, complete absence of APOC3 leads to much lower blood triglycerides after meal consumption [4].

Discoveries like these are possible if ancestry informative markers are well defined. Instead of relying on self-reported information, these markers can be used to determine the population and ancestry in research studies.

\section{Availability of DNA interpretation tools}

Democratization of genetic tests much like other pathology tests is inevitable. Databases like Clinvar, dbSNP, COSMIC etc. are going to be instrumental in determining pathogenic/benign variants. As genetic data becomes widely available to consumers, several tools and platforms are going to be made available for people to upload and analyze their information. Companies like Xcode Life (https://www.xcode.life) or raw data analysis tools like Promethease (https://www.promethease.com), Self-Decode (https://www. selfdecode.com), and more, provide platforms where consumers can upload their raw DNA data and get a wealth of information spanning health, wellness, nutrition, fitness, allergies etc. Like any other technology, privacy of data is a big concern and consumers should choose platforms that have friendly policies.

Additionally, consumers should be aware that a lot of this information is still complex to comprehend. It becomes important for the consumer to choose a platform that provides support and easyto-interpret reports. In the case of severe diseases, seeking help from genetic counselors and physicians is highly recommended.

\section{References}

1. Bouchard C, An P, Rice T, Skinner JS, Jack H, et al. (1999) Familial aggregation of VO2 max response to exercise training: Results from the heritage family study. J Appl Physiol 87: 1003-1008.

2. An P, Pérusse L, Rankinen T, Borecki IB, Gagnon J, et al. (2003) Familial aggregation of exercise heart rate and blood pressure in response to 20 weeks of endurance training: The heritage family study. Int J Sports Med 24: 57-62.

3. Khera AV, Chaffin M, Aragam KG, Haas ME (2018) Genome-wide polygenic scores for common diseases identify individuals with risk equivalent to monogenic mutations. Nature Genet 50: 1219-1224.

4. Saleheen D, Natarajan P, Armean IM, Zhao W, Rasheed A, et al. (2017) Human knockouts and phenotypic analysis in a cohort with a high rate of consanguinity. Nature 544: 235-239. 